G 9 $\begin{aligned} & \text { Haute école de gestion de Genève } \\ & \text { CRAG - Centre de Recherche Appliquée en Gestion } \\ & \text { Cahier de recherche }\end{aligned}$

\title{
A SIGHT FOR SORE EYES Assessing the value of view and landscape use on the housing market
}

Andrea Baranzini \& Caroline Schaerer

Cahier : No HES-SO/HEG-GE/C--07/1/1--CH

2007 


\title{
A SigHT FOR SORE EYES \\ Assessing the value of view and landscape use on the housing market
}

\section{Andrea Baranzini \& Caroline Schaerer}

\author{
Cahier de recherche
}

Avril 2007

\begin{abstract}
We apply the hedonic model to the Geneva-Switzerland rental market, in order to assess the value of view and landscape use. In that purpose, we construct a large database of about 10500 observations containing dwellings structural characteristics and combine it with environmental variables on noise and local air pollution exposure. Then, we make use of the Geneva geographic information system (GIS), in order to define landscape uses and patterns in the neighbourhood of the buildings. Finally, we define several variables in order to quantify the view at the dwelling level. We find that accessibility to various environmental amenities, landscape use and size, as well as view on them have a statistically significant impact on rents. In particular, the size and the view on the natural environment increase rents, while they lower rents in the case of the built environment. We also find that diversity in landscape uses in the building neighbourhood has a negative impact on rents, while possessing a diverse view from the dwelling increases rents.
\end{abstract}

\section{JEL classification}

R14, R52, D62, R31

\section{Keywords}

Hedonic model; rental market; housing market; view; landscape use; Geographic Information System (GIS)

\section{Acknowledgements}

We are grateful for financial support from the Swiss National Science Foundation, National Research Programme NRP 54 "Sustainable Development of the Built Environment". We thank the Geneva Cantonal Statistical Office for providing the data on rents and on some dwellings and buildings characteristics; the Geneva Cantonal Office for protection against noise for the noise data; Meteotest for the data on PM10; the Geneva Cantonal Office for Information Systems and Geomatics for providing the GIS data; Alain Dubois for technical support with the GIS data; and José Ramirez and Philippe Thalmann for helpful comments. A special thank goes to Eva Robinson for excellent assistance support in calculating GIS variables. This paper was presented at the EcoMod International Conference on Regional and Urban Modeling, Free University of Brussels, 1-2 June 2007. The usual disclaimer applies. 


\section{Introduction}

Urban parks and forests, water resorts, lake shores, farmlands, and landscape use more in general, are important elements contributing to the well-being of urban households. Indeed, parks, forests and open spaces provide several benefits, including opportunities for recreation, relief from urban stresses and congestion, as well as aesthetic externalities (e.g. a nice view) to the residents of the surrounding buildings. In addition, natural areas may provide ecological benefits, for instance by offering animal habitats and contributing to the local air and water quality. Given the development of the cities, there is a growing pressure on those areas in order to satisfy the increasing needs for housing and commercial spaces. Several movements have stimulated the debate for reorienting development practices to support diversity of neighbourhoods, accessibility of public spaces and urban design accounting for the pedestrians (e.g. see Congress of New Urbanism, 2002). Those often competing demands need to be traded-off by city planners and effective land-use regulation policies should integrate the value of the benefits of preserved open spaces. However, since several of those benefits are of public nature, the economic literature proposes various valuation methods in order to assess their value. Those methods can be broadly divided into two categories: stated and revealed preferences.

On the one hand, stated preferences methods apply contingent valuation, conjoint analysis or choice experiments in order to directly infer individuals' preferences for given environmental features or landscape uses. Contingent valuation (CV) is the most popular approach among stated preferences techniques and it is based on a structured survey which defines a hypothetical market from which to infer willingness-to-pay measures for particular landscape features (for a review of CV studies on the topic of open spaces, see McConnel and Walls, 2005). On the other hand, revealed preferences approaches make use of market information in order to infer the value of environmental and landscape characteristics. For instance, the travel cost method is based on travel expenditures and on the opportunity cost of the time spent for travelling in order to infer the value of a given site, such as a park or a natural reserve. Such an approach is however generally limited to recreational uses and we are unaware of studies applying the travel cost method in the urban context (see Baranzini and Rochette, 2006; and Hanley, Shaw and Wright, 2003, for a survey). The most widespread approach used in the literature is based on the hedonic method, which disentangles market information on house price or apartment rents in order to obtain the implicit price of each characteristic of the housing bundle, including environmental amenities and landscape features. In other words, as it is well recognised by urban planners and realestate business, the hedonic method quantifies the premium residents are willing to pay for living in a dwelling that offers a comparatively better view and is located in an area possessing some particular urban features.

This paper applies the hedonic method to the rental market of the Geneva Canton, Switzerland. The three main objectives of this paper are: (1) to develop sophisticated and precise quantitative measures of view at the dwelling level; (2) to assess the impact on rents of view and type of view and (3) to quantify the economic value of different land uses. Our focus on Geneva is dictated by several reasons, in particular because it possesses a large rental market (about 85 per cent of the dwellings are rental), it has both a relatively dense city and a more dispersed rural area, and we can access several rich databases, including Geographical Information System (GIS) data. By merging different datasets and by adding GIS data, we obtain a large sample of about 10500 apartments, which contains detailed 
apartment characteristics, precise information on landscape uses, as well as quantified view variables at the dwelling level. In Section 2, we briefly present the hedonic approach and review the literature specifically focusing on open space and landscape use valuation in an urban context. Section 3 explains how we defined the variables concerning the view, landscape use and diversity. Section 4 presents the dataset and Section 5 the results, while we conclude in Section 6.

\section{Assessing view and landscape use in the hedonics literature}

The seminal work of Rosen (1974) provided the theoretical foundations of the propertyhedonic model, by assuming that heterogeneous goods are valued for their utility-bearing characteristics. Therefore, by using the hedonic approach, the implicit prices of the house attributes can be revealed from the observed prices of differentiated products and the quantities of characteristics associated with them. Given the key assumption that the housing market is competitive (see Freeman, 1993), the equilibrium hedonic price schedule reflects the locus of tangencies between the households' utility functions and landlords' cost functions. Hence, at the equilibrium, the rent $P$ is determined by the implicit price of the vector of the dwelling's characteristics, $z, P=P(z)$, which is the general form of the hedonic price model (see e.g. Palmquist, 1999). The characteristics are often decomposed in a vector of structural (for example the number of rooms), accessibility (e.g. proximity to public transportation), environmental quality (such as noise) and neighbourhood (for example proportion of green areas) variables. Hence, even if there is a missing market for a given landscape characteristics (such as proximity to or view on an urban park), by unbundling the housing product it is possible to assess the (implicit) value that individuals are revealing by their (explicit) choice in the housing market. A relatively recent but fast-growing part of the hedonic literature concentrates on the value of preserved urban landscape. Although preserved landscape is source of multiple benefits, the literature has separately analysed two of them: the recreation use of urban open spaces and their aesthetic benefits.

McConnel and Walls (2005) surveyed the studies on the value of urban open space and showed that the majority of studies have been conducted in the USA. The early studies on this topic concentrated on a few types of open spaces, generally urban parks, and simply used dummy variables to indicate whether a house is located near them. Other studies characterise more precisely the open spaces, by considering different types of them, but also their size. For instance, Lutzenhiser and Netusil (2001) consider three categories of parks in Portland, Oregon, namely "urban" parks (the majority of the area is developed for non-natural recreation activities, such as sport courts), "natural area" park (the surface is mainly preserved in natural vegetation), and "specialty" parks (the primary use of the park is related to the specialty category, e.g. a boat ramp facility). As expected, the authors show that houses near natural or speciality parks have higher prices, with price increasing with their size. On the opposite, proximity to an urban park decreases house prices, although the size of the urban park has a positive impact on prices. Other studies have confirmed that proximity to urban parks may command a lower housing price given the negative externalities resulting from busy recreation activities in those parks (e.g. see Schultz and King, 2001). In the same vein, the results of Tyrväinen (1997) for Joensuu, Finland, show that although the size of forested area increases apartment prices, proximity to a forest park lowers them, since dense forests can have a shading impact on nearby houses. On the same topic, Garrod and Willis (1992) found that deciduous trees increase house prices 
located near them, while spruce conifers decrease prices. A recent study by Anderson and West (2006) shows however that results can be sensitive to unobserved neighbourhood characteristics. When controlling for the latter with local fixed effects, they find that house prices increase with proximity to neighbourhood parks, special parks and golf courses. On the contrary, when replacing the fixed effects with a number of observable variables, house sale prices decrease with proximity to neighbourhood parks.

In addition to distance, type and size, the open space value may also depend on its status and ownership. In a study on Howard County, Maryland, Geoghegan (2002) differentiates among land uses which are "developable" (agricultural cropland, pasture, and forest) from those who are "permanent" (including parks and lands with conservation easements). The results show that proximity to either types of land uses increase house prices, but that permanently preserved open space is valued three times more than developable land. Cheshire and Sheppard (1995) concentrate on the impact of different open space ownership in two towns in England, and they found that the size of either public or private open space has a positive impact on residential property values, but only when they are sufficiently scarce. Using data for an urban region in Maryland, Irwin (2002) considers various combinations of status and ownership, as well as open space type, i.e. whether land is preserved or developable, privately or publicly held and its use (cropland, pasture and forests). Using techniques to address identification problems due to endogenous variables and unobserved spatial correlation, the paper shows that the positive impact of preserved open space is greater than developable farmland and forest. Interestingly, those results seem to indicate that permanently preserved open space is most valued for providing an absence of development, rather than being driven by particular amenity characteristics of open spaces.

A final issue in this strand of the literature refers to the impact of land-use patterns, the general question being whether the spatial distribution of various types of land uses has also an impact on housing prices. This specific question was firstly addressed by Geoghegan et al. (1997), who discussed various spatial landscape indices developed in the ecology domain, in order to measure e.g. landscape diversity, fragmentation and contagion (see also Dumas et al., 2006). However, the expected impact of landscape pattern on house prices is a priori not known. For instance, increasing diversity may be preferred since it could imply proximity to various activities, such as recreation, shopping, workplaces; on the contrary, high diversity can lower housing prices, if it is associated with chaotic land-use planning. Geoghegan et al (1997) show that landscape diversity and fragmentation in the immediate neighbourhood of the properties have generally a negative impact on their prices. However, the impact is reversed for the highly developed suburbs (of Washington DC) of their sample. Using the same diversity index and an additional one measuring "richness" of land use, Acharya and Bennet (2001) confirm that the presence of open spaces increases house prices, while diversity and richness decrease them. We however note that the issue of landuse patterns has been scarcely addressed in the literature and thus more research on this topic is needed in order to discuss and confirm the previous results.

As previously mentioned, a quite separated strand of the hedonic literature focuses on the aesthetic benefits of landscapes. Of course, it is not particularly easy to characterise and measure the view from a house or an apartment. For this reason, the majority of the papers define the view variable either from direct site inspection or from household surveys. As confirmed by a recent survey of Bourassa, Hoesli and Sun (2004), the authors thus generally 
use dummy variables in order to characterise the view from a property or from an apartment. Those variables can simply inform whether or not a particular feature is visible from property (see Bond et al., 2002) or may include dwellers' subjective assessments of the quality of the view (full-quality, poor partial view, asf) (see e.g. Benson et al., 1998). Given that the view may also be interpreted as a proxy for the access to a particular feature, the distances are also included in the estimation. Therefore, in their study of the impact of the view on a lake and on land on property values in Auckland, New Zealand, Bourassa et al. (2004) included indicators for the quality of the view (narrow, medium, and wide), as well as the distance to the coast for the properties that enjoyed a water view. The majority of existing studies conclude that the view has a positive impact on residential values but that the more distant the view, the smaller the view premium.

Since this strand of the literature has to rely on surveys, it is often characterised by relatively small samples. Another and more recent part of the literature on the impact of view overcomes this problem by accessing large databases and exploiting the functionalities of geographical information systems (GIS), in order to develop sophisticated view indexes. Although subject to measurement errors, the papers using GIS data are thus not based on individual assessments, but on quantitative measures of view and neighbourhood characteristics ${ }^{1}$.

Lake et al. (1998) and Bateman et al. (2001) use the functionalities of GIS to assess the impact of road development (noise and visual intrusion) on the property prices. To this aim, they develop a quantitative measure of the features that are visible from a property, by combining land profiles with the location and height of the buildings. By accounting for the visual obstruction due to other buildings, they calculate a surface visible (a viewshed) from each property. Then, by overlying each viewshed with a land use map containing land features (such as mountains and roads), they are able to determine what is visible from each property. The view variables are thus defined at the building level. In their study for Glasgow, Scotland, they find that both the road visible from the frontyard and road noise have a negative impact on the average property prices.

Cavailhès et al. (2006) analyse the hedonic prices of the visible landscape in the urban fringe of Dijon, France. Interestingly, they not only consider the landscape that is seen from the house, but also take into account the fact that the house is visible from other spots. They distinguish between the view "from above", which describes the land-use cover in the neighbourhood of the building, and the "view from within", which takes into account the relief and objects like trees and buildings, and which thus corresponds to the actual view. They found that consumers are short-sighted since they are only willing to pay for a view up to 150 metres (or up to 300 metres for some attributes) around the house. Moreover, they find that being exposed to the view from other houses is a nuisance. Finally, they confirm that the actual view has a greater influence on real-estate than the mere land use around the property.

Paterson and Boyle (2002) also measure the extent and visibility of surrounding land uses using GIS technology. They calculate the percentage of each land use type within one

\footnotetext{
${ }^{1}$ The problem of using perceived vs. measured variables is often encountered when using hedonics to assess environmental impacts. In another paper, we analysed the relationship between subjective and scientific noise measures and their use in a hedonic framework (cf. Baranzini, Schaerer, Ramirez and Thalmann, 2006).
} 
kilometre around a property, the overall percentage of land visible within one kilometre around the property and the percentage of visible land of each land-use category. Their visibility measures are based exclusively on the topographic data of the area and thus do not account of the objects that can impede the view. They found that visibility is an important environmental variable, which omission could produce bias in the coefficient of other environmental attributes.

Referring to Swiss studies, Rieder (2005) considers Switzerland as a unique housing market, and then uses spatial econometric techniques in order to account for rent differential at the regional level. The author introduces dummy variables for lake view, river view and view on the mountains. He finds that having a view on a river has no impact on the rent. In opposition, a lake view increases rents by 2.9 per cent, while a mountain view by 0.7 per cent. Salvi et al. (2004) used the functionalities of GIS in order to calculate the view on lake and a general cleared view, in order to assess their impact on the Zurich real estate markets. For the general view, they found a significant positive impact on property prices from 2.2 per cent, for visibility ranging from 50 to $100 \mathrm{~km}^{2}$, to 3.2 per cent, for a visibility of more than $250 \mathrm{~km}^{2}$. For the lake view, the impact on single-family house prices increases from 2.6 per cent for a lake view of 5 to $20 \mathrm{~km}^{2}$, to 11.2 per cent for more than $40 \mathrm{~km}^{2}$ of visible lake surface. However, it should be noted that the view variables are defined at the hectare level in which the building is located. Moreover, as in Paterson et al. (2002), their calculations are based on topographic data and do not account for the possible barriers to the view (e.g. buildings and trees in front of the buildings). In opposition to those previous studies, in the next sections we will develop and then use original view variables at the dwelling level, which also account for view impediments.

\section{Constructing GIS-based landscape use and view variables}

In this paper, we assess the impact of land use and of view on the Geneva rental market. In addition to considering those features simultaneously, our objective is to define them precisely and at the dwelling level. To our knowledge, this is the first paper developing such view measures at the dwelling level, considering surrounding landscape uses, in an urban context and with a large sample.

We calculated the various variables characterising landscape uses surrounding each building by drawing on a very rich and well-developed GIS for Geneva. All the landscape variables are thus calculated using the same GIS data, from which we can differentiate among fourteen different land-uses. In order to limit multicolinearity issues and to reduce the number of variables, we grouped similar land-uses in the following categories: tree-covered areas (trees and forests); agricultural areas; and water-covered areas (Geneva lake and Rhone river). When grouped, those three categories will represent what we call the "natural environment". We then considered the following four categories representing what we call the "built environment": buildings-covered and constructed areas; urban parks (including sport courts); transportation areas (roads, railways and airport); and industrial areas.

Based on the previous seven land-uses categories, we defined three different types of variables:

1) Accessibility variables: those variables represent the most popular and the relatively easy application of GIS, since they can be used to measure precisely the accessibility to environmental amenities. We calculated the distance from each building to each one of 
the seven above-mentioned land-uses, e.g. the distance from the building to the nearest urban park. In addition, as in Baranzini and Ramirez (2005), we calculated the distance to major public infrastructures, such as primary schools and public transport stops.

2) Neighbourhood variables: those variables are based on landscape ecology and are used to characterise the pattern of landscape uses surrounding the buildings. We refer to Geoghegan et al. (1997) and calculate a "land-use diversity index", which measures the variety of the land-uses in the vicinity of the buildings of our sample:

$$
H=-\sum_{k=1}^{K}\left(P_{k}\right) \ln \left(P_{k}\right)
$$

where $P_{k}$ is the proportion of the area dedicated to land-use $k$ in the neighbourhood of the building, relatively to the total neighbourhood area. We calculated those surfaces in a radius of one kilometre around each building. A larger value for $H$, indicates a more diverse landscape use.

3) Aesthetic variables: those are the view variables, which are calculated at the dwelling level. The calculations of those variables are quite complicated and time-intensive, since the view variables have to account for a very large number of factors. The first step in our procedure was to use a numerical terrain model that takes account of the topographic profile of the land and to combine it with a surface numerical model, in order to account for the height of all the objects above the ground (e.g. buildings, trees). This allowed us to construct a three-dimensional layer ${ }^{2}$, which accounts for all the objects that can impede the view. Then, using complex queries, we are able to calculate the view in a radius of one kilometre ${ }^{3}$ around the centre of each building. In order to be as precise as possible, the viewshed is calculated from the central point of the building at three different observer heights: from the ground floor level (1.8 metres above terrain height), from the middle of the building (half the difference between the building surface height and the terrain height) and at the roof level (1 metre less than the building surface height). By summing up all the visible cells, we obtain the total number of hectares that is visible in a radius of one kilometre around the building, at the three different height levels. We call the resulting view variables the "small view" and we represent one of them in Figure 1a. The observer, who is symbolized by the blue line in the middle of the invisible building, is able to see the entire surface in green ${ }^{4}$. In order to characterise more precisely the type of view, we overlaid the visible surface with the previously mentioned seven land-use covers. We are thus able to measure which and how much of each land-use type is visible. The variable measuring the "view diversity index" is calculated by applying equation (1) to the surface visible of each land-use type with respect to the overall visible surface. In addition, by using the same methodology, we determine whether the dwelling

\footnotetext{
${ }^{2}$ The pixel size is one square metre.

${ }^{3}$ Given the enormous amount of information that has to be taken into account in an urban context and thus the resulting heavy calculation time, we limited the view variable to the same scale as the landscape use variables, i.e. a radius of one kilometre around the building.

${ }^{4}$ Of course, the main drawback of our approach is that we do not know the actual position of the dwelling windows (e.g. backyard or front yard). Since our methodology reported all the visible hectares, both backyard and front yard, it could well be that our calculations report a very nice front view on the lake, while the dwelling only have a backyard view. However, with respect to existing literature, which in the urban context is mainly at the building or hectare levels, we believe that our view variables represent a strong improvement.
} 
has a view on the famous Geneva Water Fountain (Jet d'eau) and on the ancient Cathedral. Since measuring precisely the surface which is viewed for the latter two variables does not make great sense, we just defined two dummy variables taking the value of one if the measured viewed surface is positive.

The resulting ground, middle or roof views are subsequently associated to each dwelling in the building according to the floor level at which it is located. This is done by assuming that each floor has a height of 3 metres and then by associating the view (ground, middle or roof) which is the closest.

The previous calculation for the view in a radius of one kilometre can provide a good approximation of the view in a city. However, it has the shortcoming of neglecting environmental amenities located further away, like a view on the mountains. We therefore constructed an unconstrained "wide view" by performing a viewshed on the topographic data only. Given the topography of the Canton of Geneva, we considered as "mountains" all the visible cells that have an altitude higher than 750 metres above sea level (the city is at about 375 metres above sea level). By summing up all of them, we obtain the total number of hectares which are visible and we call it the "mountain view". In Figure 1b, the wide view from the yellow circled building is represented in red. It can be noticed that the view calculated is quite wide since it does not account for the different barriers to the view. However, this seems a good methodology to calculate the remote features such as the mountain view.

Figure 1. Illustration of two different view measures for a given apartment in our database.

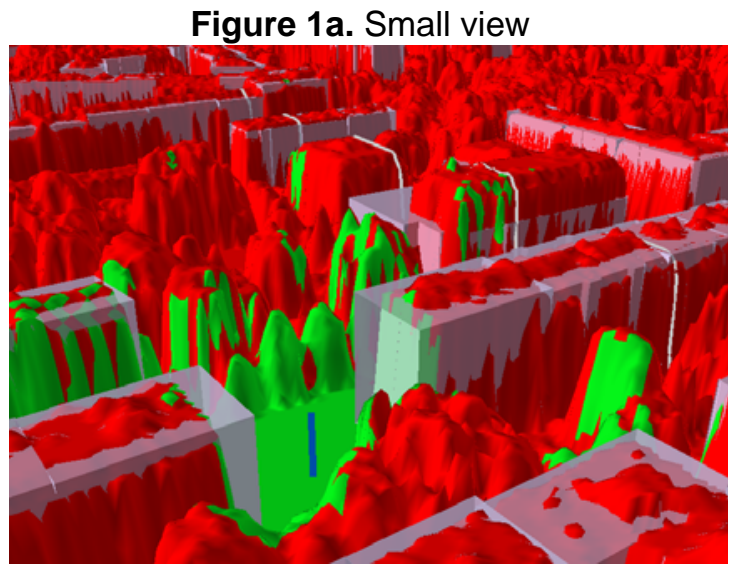

Figure 1b. Wide View

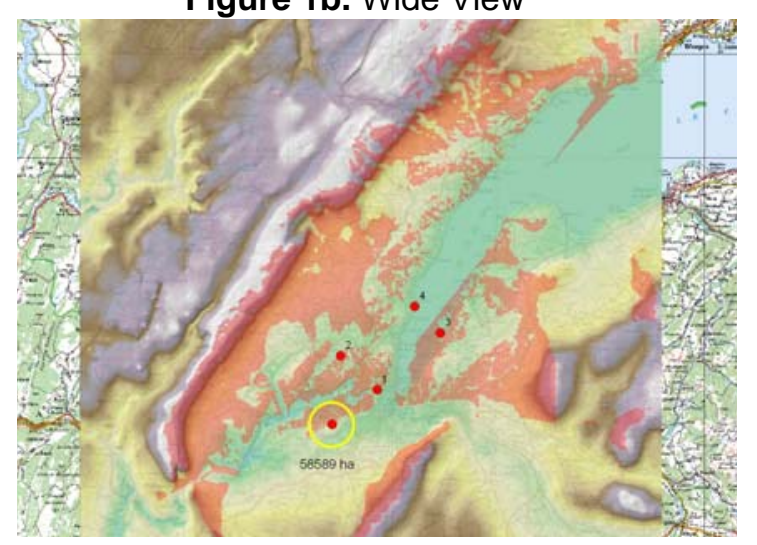




\section{Dataset and descriptive statistics}

The main data source of our study is the "Statistics on rents in the Geneva Canton" for the year 2005, issued by the Geneva Cantonal Statistical Office. The sample of this annual survey covers more than 18000 apartments in about 7700 buildings, which represents almost $1 / 8$ of the total number of dwellings rented in the Canton. It includes data on rents, year of construction, number of rooms, floor level, status of the apartment (private rental sector or public rental sector) and if there was at least one change of tenant in the last year. The database does not cover owners, individual housing and buildings with less than three apartments.

From the Geneva Cantonal Office for the protection against noise, we obtained two measures of road traffic noise: the yearly averaged daytime noise level and its dynamics. Both measures are expressed in the A-weighted decibel scale $(\mathrm{dB}(\mathrm{A}))$. The daytime noise level represents the equivalent continuous noise level averaged over 15 hours. The noise dynamics is given by the difference between the noise level which is exceeded during $10 \%$ of the time ("peak noise level") and the noise level which is exceeded $90 \%$ of the time ("background or residual noise level").

Finally, from Meteotest, an independent private company active in weather forecasts, applied meteorology and air pollution control, we obtained the data on particulate matter 10 (PM10) concentration, a measure of local air pollution, which is regulated by the Swiss legislation.

After merging all the information from these different sources and then adding our GIScalculated variables, we obtain a final sample of 10396 complete observations. Descriptive statistics are reported in Table 1.

The mean monthly rent in 2005 is about CHF 1117 for the whole sample with a very large variance $^{5}$. About 88 per cent of the buildings are private-sector rents, while the remaining buildings are mainly under direct State control. Most of the buildings in our sample were constructed between 1946 and 1960. Note that this construction year takes into account the major renovations. The mean number of rooms is about 3.6, which includes living room, bedrooms and the kitchen.

The small means for the accessibility variables to the infrastructures and the environmental amenities illustrate that the Canton of Geneva is small and dense. Interestingly, note that the mean exposure to the daily road traffic noise $\left(L r_{D}\right)$ is $65 \mathrm{~dB}(\mathrm{~A})$, a value that exceeds the legal limit of $60 \mathrm{~dB}(A)$ set in the Swiss noise regulation for the residential areas (see Swiss Noise Abatement Ordinance, art. 43), while the mean noise dynamics is equal to $8 \mathrm{~dB}(\mathrm{~A})$. However, noise is often measured for the buildings suspected to be exposed to high traffic noise, which implies that $65 \mathrm{~dB}(\mathrm{~A})$ is not representative of the average noise level in the Geneva Canton. Referring to air pollution, the mean exposure to PM10 concentration amounts to $22 \mu / \mathrm{m}^{3}$, which is slightly higher than the annual concentration legal limit of $20 \mu / \mathrm{m}^{3}$.

${ }^{5}$ Currently, CHF $1=$ USD 0.83 or EURO 0.61. 
Table 1. Descriptive statistics $(\mathrm{N}=10396)$

\begin{tabular}{|c|c|c|c|c|}
\hline Variables & Mean & Std. Dev. & Min & Max \\
\hline \multicolumn{5}{|l|}{ Structural Variables } \\
\hline Mean annual net rent & 13'398 & 6'711 & 2'508 & $120 ' 000$ \\
\hline Built between 1946 \& 1960 & 0.2328 & 0.4226 & 0 & 1 \\
\hline Built between 1961 \& 1970 & 0.2354 & 0.4243 & 0 & 1 \\
\hline Built between 1971 \& 1980 & 0.1402 & 0.3473 & 0 & 1 \\
\hline Built between 1981 \& 1990 & 0.1456 & 0.3528 & 0 & 1 \\
\hline Built after 1990 & 0.1339 & 0.3406 & 0 & 1 \\
\hline Private-sector rent & 0.8775 & 0.3279 & 0 & 1 \\
\hline Number of rooms & 3.6007 & 1.2555 & 1.5 & 10 \\
\hline Floor level & 3.4589 & 2.3714 & 0 & 22 \\
\hline Height of the building $(x 10)$ & 21.8022 & 7.0072 & 0 & 66 \\
\hline Tenancy change (in the past year) & 0.0773 & 0.2671 & 0 & 1 \\
\hline \multicolumn{5}{|l|}{ Environmental variables } \\
\hline Road traffic daytime noise $(\mathrm{dB}(\mathrm{A}))$ & 65.7429 & 5.1692 & 47 & 75 \\
\hline Road traffic noise dynamics (dB(A)) & 8.5786 & 1.5002 & 4.50 & 13.50 \\
\hline Particulate matters $10\left(\mu / \mathrm{m}^{3}\right)$ & 22.3037 & 1.4730 & 18.42 & 26.95 \\
\hline \multicolumn{5}{|l|}{ Accessibility variables } \\
\hline Distance to nearest primary school (km) & 0.2092 & 0.1004 & 0.00 & 0.76 \\
\hline Distance to city centre (km) & 2.2609 & 1.5432 & 0.08 & 9.25 \\
\hline Distance to nearest public transport stops $(\mathrm{km})$ & 0.1151 & 0.0592 & 0.00 & 0.38 \\
\hline Distance to water-covered area $(\mathrm{km})$ & 0.8111 & 0.7070 & 0.01 & 3.87 \\
\hline Distance to urban parks (km) & 0.1296 & 0.0853 & 0.00 & 0.74 \\
\hline \multicolumn{5}{|l|}{ Neighbourhood variables } \\
\hline Surface of water-covered area (ha) & 20.9903 & 32.1064 & 0.00 & 165.35 \\
\hline Surface of tree-covered area (ha) & 84.4230 & 26.2177 & 11.44 & 157.61 \\
\hline Surface of agricultural area (ha) & 8.8972 & 27.1271 & 0.00 & 211.56 \\
\hline Surface of urban parks (ha) & 17.5973 & 7.8991 & 2.79 & 49.83 \\
\hline Surface of industrial area (ha) & 8.0380 & 11.6638 & 0.00 & 98.35 \\
\hline Surface of building-covered area (ha) & 139.9197 & 29.4835 & 23.66 & 184.79 \\
\hline "Land-use" diversity indice & 1.3130 & 0.1440 & 0.96 & 1.69 \\
\hline \multicolumn{5}{|l|}{ View variables } \\
\hline View on natural environment (ha) & 0.6732 & 3.5624 & 0.00 & 106.98 \\
\hline View on built environment (ha) & 0.8365 & 2.0101 & 0.01 & 43.31 \\
\hline Ratio view natural/built environment & 0.7543 & 3.4677 & 0.00 & 145.65 \\
\hline View on water-covered area (ha) & 0.1757 & 3.0817 & 0.00 & 106.70 \\
\hline View on tree-covered area (ha) & 0.3525 & 0.8134 & 0.00 & 9.49 \\
\hline View on agricultural area (ha) & 0.1450 & 1.3585 & 0.00 & 33.25 \\
\hline View on urban parks (ha) & 0.0480 & 0.2671 & 0.00 & 6.08 \\
\hline View on industrial area (ha) & 0.0178 & 0.1341 & 0.00 & 3.07 \\
\hline "View" diversity indice & 0.8477 & 0.1997 & 0.07 & 1.62 \\
\hline View on Jet d'eau (dummy) & 0.0246 & 0.1550 & 0 & 1 \\
\hline View on ancient cathedral (dummy) & 0.0184 & 0.1343 & 0 & 1 \\
\hline Mountain view $\left(\mathrm{km}^{2}\right)$ & 165.5587 & 27.3521 & 37.21 & 228.50 \\
\hline
\end{tabular}

Concerning the neighbourhood and the aesthetic variables, both types of variables are measured in a radius of one kilometre around each building of our sample, except for the mountain view which is not constrained by any calculation radius. Figure 2 provides a graphical representation of the average value of the variable measuring the overall view on the land-use surface in the neighbourhood (which amounts to about 1.5 ha, see picture on the left) and for its maximum value in the sample (about $107 \mathrm{ha}$, see picture on the right). In the bottom of Figure 2 we give an example of a view on the lake (left) and in the country-side (right), for different levels in the building (ground and roof level). 
Figure 2. Representation of the mean and maximum overall view in a one-kilometre radius around the building (top), and views from ground and roof levels (bottom).

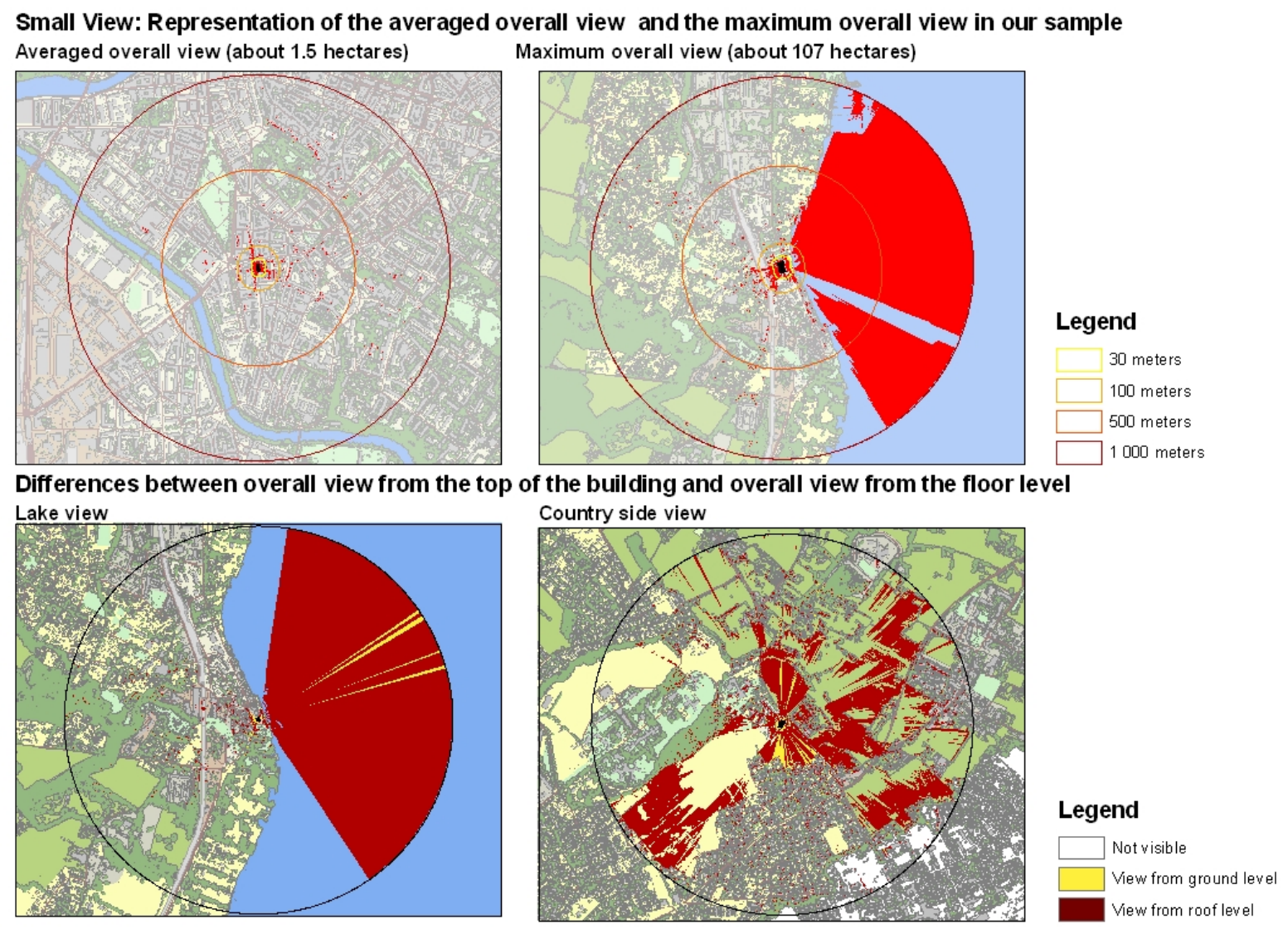

From Table 1, we note that only 2.5 per cent of the dwellings have a view on the Geneva Jet d'eau and 1.8 per cent have a view on the ancient Cathedral. In addition, there are large differences between the land use surfaces and the corresponding neighbourhood view variables. For instance, the mean surface of lake and rivers in the neighbourhood of the building is equal to 21 hectares, while the mean view from the dwelling on the lake is 0.176 hectares. Similarly, the mean surface covered by trees in the neighbourhood is equal to 84 hectares, while the mean view on trees is equal to 0.35 hectares. Given those differences, in the next empirical section, we will be able to assess whether it is the presence of an environment amenity, the view on it, or its accessibility which is rewarded on the housing market. 


\section{Empirical application and results}

In this section, we examine whether the Geneva rental market awards a premium to those dwellings which are located in the vicinity, in the area of and/or which enjoy a better view on environmental amenities.

Since the theoretical literature does not dictate any functional form for the hedonic equation, it has to be determined empirically. Linear, semi-logarithmic, log-linear, as well as linear BoxCox transformations are commonly used functional forms. Box-Cox transformations of the dependent and independent variables were jointly and alternatively tested, and the semilogarithmic functional form appears to be the most adequate form $^{6}$. More specifically, we estimate the following hedonic equation:

$$
\ln Y_{i}=\alpha+\sum_{m=1}^{M} \beta_{i m} S_{i m}+\sum_{n=1}^{N} \delta_{j n} E_{j n}+\sum_{x=1}^{X} \gamma_{j x} A_{j x}+\sum_{k=1}^{K} \phi_{j k} N_{j k}+\sum_{z=1}^{Z} \lambda_{i z} V_{i z}+\mu_{i}
$$

where $\ln Y_{i}$ is the natural logarithm of the 2005 monthly rent of dwelling $i, S_{i m}$ corresponds to structural characteristic $m$ of dwelling $i, E_{j n}$ stands for environmental characteristics $n$ at building $j$ sheltering $i, A_{j x}$ represents the accessibility characteristics of building $j$ sheltering $i$ to landscape use $x, N_{j k}$ refers to the neighbourhood characteristics $k, V_{i z}$ stands for the view attributes $z$ from dwelling $i$ and $\mu_{i}$ is an error term reflecting all the unobservable.

In order to determine which environment amenities are rewarded on the housing market, we estimate four different models. The first model, Model 1 , is the traditional model which contains only the "classic" hedonic variables. In Model 2, we add the accessibility and neighbourhood variables, while in Model 3 we introduce the overall view variables on the natural and built environment. In Model 4, we distinguish the different types of view. The results of the estimations of these models are reported in Table 2.

The analysis of simple correlation matrices indicates that there are no significant dependencies between the variables, and the variance inflation factor (vif) test confirms that there are no problems of multicolinearity. In order to eliminate heteroskedasticity problems, the White's consistent estimator of variances was used. The four models explain from 61 to 62 per cent of the variance of rents in the Canton of Geneva.

The comparison of the coefficients of Model 1 with the four alternative models shows that the coefficients are remarkably stable across the models. The statistical tests on the equality of the coefficients between the four models cannot be rejected. Almost all the variables are statistically significant and have the expected sign. Given the semi-logarithmic functional form of the estimated hedonic equation (2), the coefficients of the variables represent semielasticities, i.e. the percentage change in the rent for a given unit change in the independent variables, all the other characteristics remaining the same. For example, an additional room raises the rent by about 25 per cent on average, while the private-sector rent differential relative to the public sector amounts on average to 22 per cent. The impact of the building year of construction behaves in a somehow peculiar way, since on average the rents of the buildings built between 1946 and 1970 are lower than those built before 1946, while the rents

\footnotetext{
${ }^{6}$ Malpezzi (2002) highlighted five major advantages of the semi-logarithmic functional form: (i) The implicit price of a housing attribute is related to the quantity of the other housing attributes; (ii) The coefficients are easily interpretable in terms of semi-elasticity; (iii) It mitigates heteroskedasticity problems; (iv) It can be computed easily; and (v) Some flexibility in the specification of the independent variables can be easily introduced.
} 
of more recent buildings (since 1971) are higher. This result might arise from the fact that pre-war buildings were more massive with better sound and thermal insulation and more generous room dimensions than those that were rapidly build during the post-war housing boom. Note also that in case of a change in tenancy between 2004 and 2005, the 2005 rent is on average about 18 per cent higher, which confirms the suspicion that landlords generally seize the opportunity to raise the rent at changes in tenancy (see Thalmann, 1987).

Concerning the environmental variables, an additional decibel of road traffic noise during the day reduces the rent by 0.20 per cent on average. An increase in peak noise by $1 \mathrm{~dB}(\mathrm{~A})$ has a greater impact, since the rent is decreased by 0.76 , which is in line with acoustic studies that show the noise variability causes greater pain. Referring to local air pollution, an increase in the annual concentration of PM10 by $1 \mu / \mathrm{m}^{3}$ decreases the rent by -1 per cent. These results are comparable to the findings from other hedonic studies applied to the Geneva market (see e.g. Baranzini and Ramirez, 2005). Finally, proximity to primary school and public transport stops acts negatively on the rent, while proximity to city centre acts positively.

In Model 2, we add the GIS-constructed accessibility and the neighbourhood variables. Note that some accessibility and neighbourhood variables were not tested due to correlation problem (e.g. distance to nearest agricultural area, surface of transportation area, distance to transportation area) with another variable; other variables were set aside because meaningless (e.g. distance to the nearest tree).

The positive and significant coefficients for both the accessibility and the surface of watercovered area in the neighbourhood of the dwelling imply that those characteristics have a positive impact on rent. This result suggests that people are willing to pay a premium to live closer to large sized water-areas. The same result is found for the surface of trees-covered and agricultural areas. On the contrary, proximity to urban parks imply a lower rent, while their size in the neighbourhood is not significant. A similar result was found by Lutzenhiser et al. (2001) and Schultz and King (2001), who suggested that busy urban parks may generate negative externalities. As expected, the surface of building-covered areas acts negatively on the rent, while industrial areas are not significant. This confirms that it is undesirable to live in a heavily constructed area.

As already discussed, a priori there is no expectation about the sign of the coefficient of the diversity index. In the case of Geneva, Table 2 reports a negative statistically significant coefficient for the land-use diversity index, meaning that landscape use heterogeneity implies a decrease in rent, all else equal. This result is in line with what was found by Geoghegan et al (1997) and Acharya and Bennet (2001). 
Table 2. Estimation results $(\mathrm{N}=10396)$

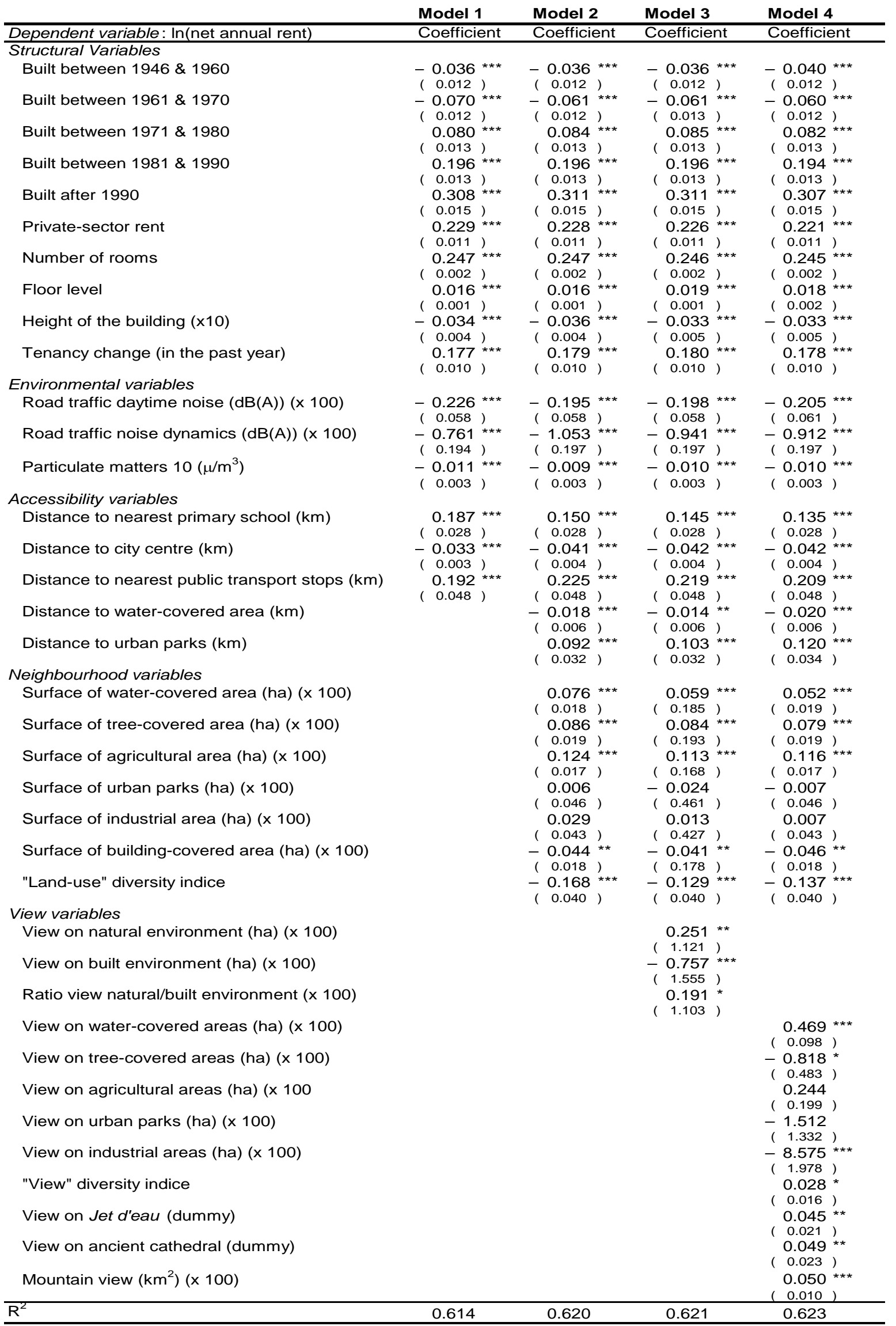

Notes: ${ }^{* \star}$ significant at the 0.01 level; ${ }^{* *}$ significant at the 0.05 level; ${ }^{*}$ significant at the 0.10 level; standard errors in brackets. The reference for the period of construction is a building built before 1946 . 
In Model 3, we introduced two additional variables, measuring the view from the dwelling on the surrounding natural and built environment. The variables are significant with the expected sign. The view on an additional hectare of natural landscape increases the rent by 0.25 per cent, while the view on the built environment decreases rents by 0.76 per cent. We also introduced a variable measuring the ratio of the view on natural over the built environment. The positive coefficient associated with this variable indicates that rents increase as well when the relative size of the view on the natural environment increases ${ }^{7}$. More in general, the results of Model 3 indicate that the residents not only value the presence of natural environmental amenities in their neighbourhood, but also their view on them.

Therefore, in Model 4 we investigate more precisely which type of landscape views has an impact on rents. To this aim, we distinguish for the type of view according to the various landuse covers as well as the "wide view" on the mountains. Note that the view on the buildingcovered area is dropped from the estimation of Model 4, since this variable is highly correlated (84 per cent) with the view on tree-covered areas. More interestingly, we can observe that while the size of agricultural areas in the neighbourhood is statistically significant and positive, the view on those areas is not significant. This suggests that the presence of the agricultural areas in the neighbourhood has a positive influence on the rents, whether these areas are visible or not. For industrial areas, the result is reversed. Indeed, the size of industrial areas in the neighbourhood is not significant, while the extent of their visibility has a statistically significant negative impact: a dwelling with an additional hectare of view on industrial area will reduce the rent 8.6 per cent. The relatively high coefficient associated with the view on industrial areas should be interpreted by considering that the maximum view on those areas area amounts to 3 hectares, so that an additional hectare of industrial area is relatively large.

As expected, a view on the water-covered area has a positive impact on rents. The associated coefficient of 0.47 per cent per additional hectare of lake/river view does not detract the significant and stable coefficients associated with the size and the distance to water amenities. On the opposite, our results show that a view on trees has a negative impact on rents, while a greater tree-covered surface increases rents. A similar result was reported by Des Rosiers et al. (2002), who found that an-above average density of the vegetation visible from the property had a significant negative effect on prices. This result could be explained by an excessive tree cover or because forests are not much appreciated as a view, being rather dark and monotonous.

It is interesting to mention that in opposition to the "land-use diversity index", which has a negative impact on the rents, in Model 4 we find that the diversity of the view acts positively on the rents. This means that diversity in landscape uses in the neighbouring of the buildings is negatively valued, while possessing a view on a diverse landscape is appreciated.

Finally, Model 4 contains a variable measuring the distant view on the mountains surrounding Geneva: the associated coefficient is positive and significant. The last two GIScalculated dummies, the view on the famous Geneva Jet d'eau and on the ancient Cathedral, both increase the rent by 4.5 per cent and 4.9 per cent, respectively.

\footnotetext{
${ }^{7}$ We also tested a model similar to Model 3, but with neighbourhood variables grouped by "natural" and "built" land use types, and with the natural over built land uses ratio. Although those variables are highly correlated, we notice that the coefficient associated with the natural/built ratio is significant and positive.
} 


\section{Conclusions}

The aim of this paper was to develop and to incorporate original neighbourhood and aesthetic environmental variables in a hedonic model and to test their impact on Geneva's rental market. After having computed precise measures of the view and landscape uses at the dwelling level in a radius of one-kilometre around each building, we tested four different hedonic models: to the "traditional" model, we added in turn accessibility and neighbourhood variables, overall view variables and finally type-specific view variables. To our knowledge, this paper is the first attempt to simultaneously incorporate into a hedonic model landscape uses and view variables at the dwelling level in an urban context with a very large sample of about 10500 complete observations.

Our results show that both land-use and aesthetic variables significantly affect Geneva rents, in addition to the mere proximity of the different land-use covers. We find that accessibility to various environmental amenities, landscape use and size, as well as view on them have a statistically significant impact on rents. In particular, the size and the view on the natural environment increase rents, while it lowers rents in the case of the built environment. We also find that diversity in landscape uses in the building neighbourhood has a negative impact on rents, while possessing a diverse view from the dwelling increases rents.

Looking at the various landscape uses more precisely, we find that proximity, size and view on water amenities increases rents. A greater wide view on the mountains has also a positive impact on rents. On the contrary, proximity and the size of urban parks affect rents negatively, as do the size of building-covered areas and the view on industrial areas. The surface of tree-covered areas in the neighbourhood of the building increase rents, but a view on them has a negative impact. Finally, dwellings with a view on the famous Geneva Jet d'eau and on the ancient cathedral are rented at a higher price.

We are currently working to expand this paper in two directions. Firstly, we would like to differentiate among land-uses depending on their status, in order to test whether the "developable land" status affects the amenity values of given landscape types, along the lines of the contribution by Irwin (2002). Secondly, we are constructing several socioeconomic indicators, in order to test for the presence of spatial concentration (socioeconomic segregation), and in that event to determine whether this socio-economic pattern has an impact on rents, in addition to landscape uses patterns. This will also allow us to analyse if some categories of households in Geneva are more exposed to environmental nuisances than others, without adequate compensation through lower rents. This future research will open the doors to discuss the existence of a household effect (cf. price discrimination) and/or a neighbourhood effect (cf. prejudice) on the Geneva housing market. 


\section{References}

Acharya, G., Bennett, L.L. (2001): "Valuing open space and land-use patterns in urban watersheds." Journal of Real Estate Finance and Economics, 22(2): 221-237.

Anderson, S.T., West, S.E. (2006):"Open space, residential property values, and spatial context." Regional Science and Urban Economics, 23: 776-789.

Baranzini, A., Schaerer, C. Ramirez, J. \& Thalmann, P. (2006): "Feel it or Measure it. Perceived vs. Measured Noise in Hedonic Models." Genève: Haute École de Gestion de Genève, Cahier de recherche HES-SO/HEG-GE/C-06/7/1-CH, available at SSRN : http://ssrn.com/abstract=937259.

Baranzini, A., Rochette, D. (2006): "The Recreation Demand for a Protected Natural Area: An Application to the Bois de Finges, Switzerland." Genève: Haute École de Gestion de Genève, Cahier de recherche HES-SO/HEG-GE/C-06/1/1-CH. Available at SSRN: http://ssrn.com/abstract=911575.

Baranzini, A., Ramirez, J. (2005): "Paying for quietness: the impact of noise on Geneva rents." Urban studies, 42(4): 633-646.

Bateman, I.J., Jones, A.P., Lovett, A.A., Lake, I.R. \& Day, B.H. (2001A): "Applying Geographical Information Systems (GIS) to Environmental and Resource Economics." Environmental and Resource Economics, 22: 219-269.

Benson, E.D., Hansen, Schwartz Jr., J.L., Smersh, G. T. (1998): "Pricing Residential amenities: the value of a view." Journal of Real estate finance and economics, 16(1), 5573.

Bond, M.T., Seiler, V.L., Seiler M.J. (2002): "Residential Real Estate Prices: A room with a view." Journal of Real Estate Research, 23(1/2): 129-137.

Bourassa, S.C., Hoesli, M. \& Sun, J. (2004): "What's in a View?" Environment and Planning A, 36: 1427-1450.

Cavailhès, J., Brossard, T., Foltête, J.-C., Hilal, M., Joly, D., Tourneux, F-P-. Tritz, C., Wavresky, P. (2006) : "Seeing and being seen : a GIS-based hedonic price valuation of landscape." Presented at the 1ère Rencontre du Logement, Marseille, Octobre 2006.

Cheshire, P.C., Sheppard, S.C. (1995): "On the price of land and the value of amenities." Economica, 62: 247-267.

Congress of New Urbanism, 2002: http://www.cnu.org.

Des Rosiers, F. Théraul, M., Kestens, Y., Villeneuve, P. (2002): "Landscaping and house values: an empirical investigation." Journal of Real Estate Research, 23:139-161.

Dumas, E., Geniaux, G., Napoleone, C. (2006): "Effects of Landscape Ecology Indices on a Real Estate Market." Presented at the 1ère Rencontre du Logement, Marseille, Octobre 2006.

Freeman, A. M. (1993): "The Measurement of Environmental and Resource Values: Theory and Methods", Resources for the Future, Washington, DC

Garrod, G.D., Willis K.G. (1992): "Valuing good's characteristics: an application of the hedonic price method to environmental attributes." Journal of Environmental Management, 34: 59-76. 
Geoghegan, J., Wainger, L.A. \& Bockstael, N.E. (1997): "Spatial landscape indices in a hedonic framework: an ecological economics analysis using GIS." Ecological Economics 23: 251-264.

Geoghegan, J. (2002): "The value of open spaces in residential land use." Land Use Policy, 19(1): 91-98.

Hanley, N., Shaw, W.D., Wright, R.E. (2003): The New Economics of Outdoor Recreation. Cheltenham: Edward Elgar.

Irwin, G.E. (2002): "The effects of open space on residential property values." Land Economics, 78(4): 465-480.

Lake, I.R., Lovett, A.A., Bateman, I.A, Langford, I.H. (1998): "Modelling environmental influences on property prices in an urban environment." Computers, Environment and Urban Systems, 22(2): 121-136.

Lutzenhiser, M., Netusil, N.R. (2001): "The effect of open spaces on a home's sale price." Contemporary Economic Policy, 19 (3): 291-298.

Malpezzi, S. (2002): "Hedonic pricing models: A selective and applied review", Prepared for Housing Economics: Essays in Honor of Duncan Maclennan. Edited by K. Gibbs and A. O'Sullivan.

McConnel, V., Walls, M. (2005): "The Value of Open Space: Evidence from Studies of NonMarket Benefits.". Washington DC: Resources for the Future, RFF Report.

Palmquist, R.B. (1999): "Hedonic Models." In J.C.J.M van den Bergh (Ed.), Handbook of Environmental and Resource Economics. Cheltenham: Edward Elgar, 765-776.

Paterson, R. W., Boyle, K. J. (2002): "Out of sight, out of mind? Using GIS to incorporate visibility in hedonic property value models." Land Economics, 78(3): 417-425.

Rieder, T. (2005): "Die Bestimmung des Mieten in der Schweiz." Lizenzarbeit, Volkswirtschfliches Institut, Abteilung Ökonometrie, Univesität Bern, 1-43.

Rosen, S. (1974): "Hedonic Prices and Implicit Markets: Product Differentiation in Pure Competition." Journal of Political Economy, 82: 34-55.

Salvi, Marco and Schellenbauer, Patrik (2004): Preise, Mieten und Renditen: Der Immobilienmarkt transparent gemacht. Zurich: Zurich Kantonal Bank.

Schultz, S.D., King, D.A. (2001): "The Use of Census Data for Hedonic Price Estimates of Open-Space Amenities and Land Use." Journal of Real Estate Finance and Economics, 22 $(2,3): 239-252$.

Thalmann, P. (1987): "Explication empirique des loyers lausannois". Swiss Journal of Economics and Statistics, 1: 47-69.

Tyrväinen, L., Miettinen, A. (2000): "Property prices and urban forest amenities." Journal of Environmental Economics and Management, 39 (2): 205-223.

Tyrväinen, L. (1997): "The Amenity Value of the Urban Forest: An Application of the Hedonic Pricing Method." Landscape and Urban Planning, 37: 211-222. 
Cahiers de recherche du Centre de Recherche Appliquée en Gestion (CRAG) de la Haute Ecole de Gestion - Genève

\section{(C) 2007}

CRAG - Centre de Recherche Appliquée en Gestion

Haute école de gestion - Genève

Campus de Battelle, Bâtiment $\mathrm{F}$

7 , route de Drize - 1227 Carouge - Suisse

$\bowtie$ crag@hesge.ch

www.hesge.ch/heg/crag

(ग) +41223881818

且 +41223881740

\section{6}

- $\mathrm{N}^{\circ} \mathrm{HES}-\mathrm{SO} / \mathrm{HEG}-\mathrm{GE} / \mathrm{C}-\mathrm{-06/1/1--CH}$

Andrea BARANZINI

Damien ROCHETTE

"La demande de récréation pour un parc naturel

Une application au Bois de Pfyn-Finges, Suisse"

- $N^{\circ}$ HES-SO/HEG-GE/C--06/2/1--CH

Giovanni FERRO LUZZI

Yves FLÜCKIGER

Sylvain WEBER

"A Cluster Analysis of Multidimentional Poverty in Switzerland"

- $\quad \mathrm{N}^{\circ} \mathrm{HES}-\mathrm{SO} / \mathrm{HEG}-\mathrm{GE} / \mathrm{C}--06 / 3 / 1--\mathrm{CH}$

Giovanni FERRO LUZZI

Sylvain WEBER

"Measuring the Performance of Microfinance Institutions"

- $\quad N^{\circ}$ HES-SO/HEG-GE/C--06/4/1--CH

Jennifer D'URSO

"L'eau de boisson :

Aspects logistiques et attitude du consommateur"

- $\quad \mathrm{N}^{\circ} \mathrm{HES}-\mathrm{SO} / \mathrm{HEG}-\mathrm{GE} / \mathrm{C}-\mathrm{-06/5/1--CH}$

Jennifer D'URSO

"La gestion publique de l'eau en Suisse"

- $\mathrm{N}^{\circ} \mathrm{HES}-\mathrm{SO} / \mathrm{HEG}-\mathrm{GE} / \mathrm{C}-\mathrm{-06/6/1-- \textrm {CH }}$

Philippe THALMANN

Andrea BARANZINI

"Gradual Introduction of Coercive Instruments in Climate Policy" 
- $\quad \mathrm{N}^{\circ} \mathrm{HES}-\mathrm{SO} / \mathrm{HEG}-\mathrm{GE} / \mathrm{C}--06 / 7 / 1--\mathrm{CH}$

Andrea BARANZINI

Caroline SCHAERER

José RAMIREZ

Philippe THALMANN

"Feel it or Measure it.

Perceived vs. Measured Noise in Hedonic Models"

- $\quad \mathrm{N}^{\circ} \mathrm{HES}-\mathrm{SO} / \mathrm{HEG}-\mathrm{GE} / \mathrm{C}--06 / 8 / 1--\mathrm{CH}$

José RAMIREZ

Anatoli VASSILIEV

"An Efficiency Comparison of Regional Employment Offices Operating under Different

Exogenous Conditions"

- $\quad \mathrm{N}^{\circ} \mathrm{HES}-\mathrm{SO} / \mathrm{HEG}-\mathrm{GE} / \mathrm{C}--06 / 9 / 1--\mathrm{CH}$

José RAMIREZ

Joseph DEUTSCH

Yves FLÜCKIGER

Jacques SILBER

"Export Activity and Wage Dispersion: The Case of Swiss Firms"

- $\quad N^{\circ}$ HES-SO/HEG-GE/C--06/10/1--CH

Joëlle DEBELY

Gaëtan DERACHE

Emmanuel FRAGNIERE

Jean TUBEROSA

"Rapport d'enquête : sondage Infobésité"

- $\quad \mathrm{N}^{\circ} \mathrm{HES}-\mathrm{SO} / \mathrm{HEG}-\mathrm{GE} / \mathrm{C}--06 / 11 / 1--\mathrm{CH}$

Andrea BARANZINI

José RAMIREZ

Cristian UGARTE ROMERO

"Les déterminants du choix de (dé)localisation des entreprises en Suisse"

- $\quad \mathrm{N}^{\circ} \mathrm{HES}-\mathrm{SO} / \mathrm{HEG}-\mathrm{GE} / \mathrm{C}--06 / 12 / 1--\mathrm{CH}$

Catherine EQUEY BALZLI

Jean TUBEROSA

David MARADAN

Marie-Eve ZUFFEREY BERSIER

"Étude du comportement des PME/PMI suisses en matière d'adoption de système de gestion intégré.

Entre méconnaissance et satisfaction."

- $\quad \mathrm{N}^{\circ} \mathrm{HES}-\mathrm{SO} / \mathrm{HEG}-\mathrm{GE} / \mathrm{C}--06 / 13 / 1--\mathrm{CH}$

Joëlle DEBELY

Magali DUBOSSON

Emmanuel Fragnière

"The pricing of the knowledge-based services : Insight from the environmental sciences" 